Abstracta Iranica Iranica

Revue bibliographique pour le domaine irano-aryen

Volume 32-33 | 2013

Comptes rendus des publications de 2009-2010

\title{
Chistopher Tuplin. Xenophon and Achaemenid Courts: A Survey of Evidence
}

\section{Astrid Nunn}

\section{OpenEdition}

1 Journals

\section{Édition électronique}

URL : http://journals.openedition.org/abstractairanica/40434

DOI : 10.4000/abstractairanica.40434

ISSN : 1961-960X

Éditeur :

CNRS (UMR 7528 Mondes iraniens et indiens), Éditions de l'IFRI

\section{Édition imprimée}

Date de publication : 1 décembre 2013

ISSN : 0240-8910

\section{Référence électronique}

Astrid Nunn, "Chistopher Tuplin. Xenophon and Achaemenid Courts: A Survey of Evidence », Abstracta Iranica [En ligne], Volume 32-33 | 2013, document 127, mis en ligne le 01 juillet 2016, consulté le 28 septembre 2020. URL : http://journals.openedition.org/abstractairanica/40434 ; DOI : https://doi.org/ 10.4000 /abstractairanica.40434

Ce document a été généré automatiquement le 28 septembre 2020.

Tous droits réservés 


\title{
Chistopher Tuplin. Xenophon and Achaemenid Courts: A Survey of Evidence
}

\author{
Astrid Nunn
}

\section{RÉFÉRENCE}

Chistopher Tuplin. « Xenophon and Achaemenid Courts: A Survey of Evidence », in : Bruno Jacobs, Robert Rollinger, eds., « Der Achämenidenhof / The Achaemenid Court ». Akten des 2. Internationalen Quolloquiums zum Thema « Vorderasien im Spannungsfeld klassischer und altorientalischer Überlieferungen », Landgut Castelen bei Basel, 23.-25. Mai 2007. Wiesbaden, 2010, p. 189-230. (Classica et Orientalia(CLeO), 2)

1 L'approche de CT est aussi bien documentée mais plus conventionnelle que celle de R. Bichler (c.r. $n^{\circ}$ 36). L'A. débute par une analyse du vocabulaire ayant trait à l'Empire achéménide dans les œuvres de Xénophon. Il en découle que Xénophon n'a pas de notions précises de l'empire achéménide. Ni les paysages, ni les villes, ni leurs palais ne sont décrits en détail. La vie aulique se base selon lui plus sur l'honneur et la performance que sur l'origine. En tout, l'apport de Xénophon pour une connaissance solide de l'empire perse est plutôt décevant. 


\section{AUTEURS}

\section{ASTRID NUNN}

Université de Munich 